\title{
Analisis Beban Kerja Mental Pada Mekanik Menggunakan Metode SWAT dan Metode QNBM
}

\author{
${ }^{1}$ Yolanda Lapai, ${ }^{2}$ Idham Halid Lahay, ${ }^{3}$ Fentje Abdul Rauf \\ 1,2,3 Jurusan Teknik Industri, Fakultas Teknik, Universitas Negeri Gorontalo \\ e-mail: yolandalapai7@gmail.com
}

\begin{abstract}
Abstrak
Beban kerja mental merupakan selisih antara tuntutan beban kerja dari suatu tugas dengan kapasitas maksimum beban mental seseorang dalam keadaan termotivasi. Tujuan dari penelitian ini adalah mengetahui tingkat beban mental pada mekanik menggunakan Metode SWAT dan QNBM. Hasil metode Subjective Workload Assesment Technique untuk service berat presentasinya adalah $56.6 \%$ kategori terbebani, dengan dimensi beban kerja mental untuk mekanik 1 dan 3 adalah effort load, pada mekanik 2 adalah time load, service ringan adalah $11.11 \%$, kategori tidak terbebani pada dimensi time load untuk semua mekanik. Metode Quistionnaire Nordic Body Map dengan persentase adalah 67\% termasuk dalam kategori sakit.
\end{abstract}

Kata kunci: SWAT, QNBM, Beban Kerja Mental

\begin{abstract}
Mental workload is the difference between the demands of a task workload with the maximum capacity of a person's mental capability in a motivated state. The purpose of this study was to determine the level of the mental burden of mechanics using the SWAT and QNBM methods. The results of the Subjective Workload Assessment Technique method for heavy service workload showed that the mechanics were $56.6 \%$ burdened. Mental workload dimensions for mechanics 1 and 3 are effort load, for mechanic 2 is time load. The category for light service is $11.11 \%$, unburdened in the time load dimension for all mechanics. Nordic Body Map Questionnaire Method was 67\%, with illness category included.
\end{abstract}

Keywords: SWAT, QNBM, Mental Workload

\section{Pendahuluan}

Produktivitas merupakan perencanaan pengembangan industri sebagai dimensi persaingan perusahaan pada umumnya. Jangkauan persaingan dapat berjalan dengan lancar karena adanya dukungan salah satu indikasi sumber daya manusia. Sumber daya manusia atau tenaga kerja sebagai aset penggerak utama dalam suatu organisasi. Sebagai penggerak, tenaga kerja dituntut untuk menyelesaikan tugas secara tepat waktu untuk mencapai hasil yang optimal. Akibat dari tuntutan tersebut, kesadaran yang dimiliki oleh tenaga kerja terabaikan karena tumpang tindinya pekerjaan secara terus menurus. Tuntutan tugas yang berlebih memberikan pengaruh terhadap beban kerja mental.

Beban kerja mental merupakan beban kerja yang merupakan selisih antara tuntutan beban kerja dari suatu tugas dengan kapasitas maksimum beban mental 
seseorang dalam keadaan termotivasi. Beban kerja mental yang berlebih dapat memunculkan stres kerja. Stres kerja merupakan kejadian-kejadian disekitar kerja. Stres kerja disebabkan beban kerja yang diterima dapat melampui batas-batas kemampuan pekerja (kapasitas pekerja) yang berlangsung dalam periode waktu yang relatif lama pada situasi dan dalam kondisi tertentu. Sebagai bagian dari sistem K3 Nasional secara keseluruhan, Indonesia harus terus mendorong dan melaksanakan kesehatan dan keselamatan, Termasuk kesehatan mental. Aktifitas pada PT. XYZ untuk bagian mekanik tugasnya melayani konsumen untuk melaksanakan perbaikan kendaraanya. Tuntutan tugas mekanik harus menyelesaikan perbaikan kerusakan dengan jumlah unit kendaraan yang masuk setiap harinya.

PT. XYZ Cabang Gorontalo adalah salah satu perusahaan swasta bergerak bidang penjualan kendaraan bermotor roda dua dan tidak hanya bergerak pada bagian penjualan juga bagian service. Bagian service terdapat 3 mekanik yang kegiatan sehari-harinya melakukan perbaikan kerusakan kendaraan. Berdasarkan observasi awal perbaikan kendaraan servis ringan maksimal 20 unit/hari, untuk kendaraan servis berat maksimal 10 unit/hari dengan capaian target untuk sebulan dapat menyelesaikan 210 unit kendaraan dalam mencapai standar upah. Banyaknya kendaraan yang masuk untuk menyelesaikan tuntutan pekerjaan dalam pencapaian standar upah memicu terjadinya beban mental terhadap mekanik. Hal ini memberikan pengaruh kesehatan pekerja berdasarkan pandangan ergonomi.

Berdasarkan latar belakang yang ada perlu adanya penelitian untuk mendeskripsikan dimensi beban kerja dan keluhan yang dirasakan mekanik pada saat bekerja.

\section{Metode}

\section{Subjective Workload Assessment Technique (SWAT)}

SWAT (Subjective Workload Assement Technique) adalah prosedur pemberian skala yang disalin untuk tugas penting yang banyak dari seseorang/individu yang berpengaruh pada mental serta berhubungan dengan pelaksanaan/performansi tugas yang bervariasi. Metode ini dikembangkan oleh Reid dan Nygren dengan menggunakan dasar metode pengskalaan conjoint. SWAT berbeda dengan pengukuran subjektif lainya karna dikembangkan dengan teliti dan akar pada teori pengukuran formal, khususnya teori pengukuran conjoint (Hutabarat, 2018). Pengumpulan data dengan metode analisis SWAT dilakukan melalui pemakaian kartukartu kombinasi beban kerja mental, yaitu berupa lembaran yang dibuat secara khusus dan berjumlah 27 buah (Saputra dkk, 2019). Metode SWAT (Subjective Workload 
Assement Technique) menggambarkan sistem kerja sebagai model multi dimensional terdiri dari tiga dimensi yaitu faktor beban waktu (time load), beban usaha (mental effort load), dan beban psikologis (psychological stress load) (Rahayuningsih, 2014).

Quistionnaire Nordic Body Map (QNBM)

Nordic body map sistem pengukuran keluhan sakit pada tubuh. Metode Nordic body map merupakan metode penilaian yang sangat subjektif artinya keberhasilan aplikasi metode ini sangat tergantung dari kondisi dan situasi dialami pekerja pada saat dilakukanya penelitian dan juga tergantung keahlian dan pengalaman ebsorver yang bersangkutan. Kuisioner Nordic Body Map ini telah secara luas digunakan oleh para ahli ergonomi untuk menilai tingkat keparahan gangguan pada sistem muskuloskeletal dan mempunyai validitas dan reabilitas yang cukup (Rahansyah, 2019).

\section{Hasil dan Pembahasan}

Hasil

Subjective Workload Assessment Technique (SWAT)

Scale deplopment mekanik (servis berat) merupakan hasil pengurutan kartu berdasarkan ativitas servis berat oleh mekanik. Pengurutan kartu menentukan hasil skala akhir untuk mengetahui beban kerja mental berdasarka aktivitas oleh setiap individu atau kelompok dan beban kerja mental berdasarkan hasil pengurutan kartu oleh setiap subjektif penelitian yang dapat diketahui dari prototype. Tabel 1 menunjukan langkah pertama dari hasil pengurutan kartu dengan nilai koefisien melebihi 0.75 maka dilakukan Group Scalling Solution (GSS). Dengan prototype beban kerja pada mekanik 1 dan 3 adalah 0.81 ( E ) artinya pekerja 1 mengalami Workload Effort sedangkan pekerja 2 adalah 0.80 ( T ) artinya pekerja 2 mengalami Workload Time.

Tabel 1 Hasil Prototype Corelations and Kendal's

\begin{tabular}{cccccccc}
\hline Sub & TES & TSE & ETS & EST & SET & STE & prototype \\
\hline 1 & 0.73 & 0.70 & 0.81 & 0.81 & 0.73 & 0.73 & E \\
2 & 0.80 & 0.79 & 0.77 & 0.75 & 0.70 & 0.71 & T \\
3 & .73 & 0.70 & 0.81 & 0.81 & 0.73 & 0.70 & E \\
\hline
\end{tabular}

Hasil nilai skala SWAT (Subjetive Workload Assement Technique) diperoleh dari pengurutan kartu oleh subjek penelitian. Tabel 2 mewakili nilai skala akhir dari ke 3 subjek penilitian yaitu mekanik, hal ini berdasarkan nilai koefisien kesepakatan Kendal yang melebihi 0.75 pada tabel 1 . 
Tabel 2 Hasil Group Scale Solution

\begin{tabular}{|c|c|c|c|c|c|}
\hline \multirow[b]{2}{*}{ No } & \multirow[b]{2}{*}{ Huruf } & \multicolumn{3}{|c|}{ Kombinasi Beban Kerja } & \multirow[b]{2}{*}{$\begin{array}{c}\text { Nilai Skala } \\
\text { Mekanik }\end{array}$} \\
\hline & & $\begin{array}{l}\text { Time } \\
(\mathrm{T})\end{array}$ & $\begin{array}{l}\text { Effort } \\
\text { (E) }\end{array}$ & $\begin{array}{l}\text { Stress } \\
\text { (S) }\end{array}$ & \\
\hline 1 & $\mathrm{~N}$ & 1 & 1 & 1 & .0 \\
\hline 2 & $\mathrm{~B}$ & 1 & 1 & 2 & 17.1 \\
\hline 3 & W & 1 & 1 & 3 & 35.2 \\
\hline 4 & $\mathrm{~F}$ & 1 & 2 & 1 & 15.8 \\
\hline 5 & $J$ & 1 & 2 & 2 & 32.9 \\
\hline 6 & $\mathrm{C}$ & 1 & 2 & 3 & 51.0 \\
\hline 7 & $x$ & 1 & 3 & 1 & 31.9 \\
\hline 8 & $S$ & 1 & 3 & 2 & 49.1 \\
\hline 9 & $M$ & 1 & 3 & 3 & 67.2 \\
\hline 10 & $U$ & 2 & 1 & 1 & 19.6 \\
\hline 11 & $\mathrm{G}$ & 2 & 1 & 2 & 36.7 \\
\hline 12 & $\mathrm{Z}$ & 2 & 1 & 3 & 54.8 \\
\hline 13 & V & 2 & 2 & 1 & 35.3 \\
\hline 14 & Q & 2 & 2 & 2 & 52.5 \\
\hline 15 & $\mathrm{ZZ}$ & 2 & 2 & 3 & 70.6 \\
\hline 16 & $\mathrm{~K}$ & 2 & 3 & 1 & 51.5 \\
\hline 17 & $E$ & 2 & 3 & 2 & 68.6 \\
\hline 18 & $\mathrm{R}$ & 2 & 3 & 3 & 86.7 \\
\hline 19 & $\mathrm{H}$ & 3 & 1 & 1 & 32.8 \\
\hline 20 & $P$ & 3 & 1 & 2 & 50.0 \\
\hline 21 & $\mathrm{D}$ & 3 & 1 & 3 & 68.1 \\
\hline 22 & $Y$ & 3 & 2 & 1 & 48.6 \\
\hline 23 & $A$ & 3 & 2 & 2 & 65.8 \\
\hline 24 & 0 & 3 & 2 & 3 & 83.9 \\
\hline 25 & L & 3 & 3 & 1 & 64.8 \\
\hline 26 & $\mathrm{~T}$ & 3 & 3 & 2 & 81.9 \\
\hline 27 & 1 & 3 & 3 & 3 & 100.0 \\
\hline
\end{tabular}

Tabel 2 meruakan hasil dari skala akhir untuk servis berat dengan hasil yang didapatkan persentase beban kerja mental adalah berdasarkan kelompok sebesar $56.6 \%$ yang dikategorikan sedang, dengan prototype dimensi time, effort, stress menonjol pada mekanik 1 adalah effort yang artinya lebih mengalami beban usaha yang dikeluarkan, pada mekanik 2 adalah time yang artinya lebih mengalami beban usaha waktu dimana mekanik merasa pekerjaan yang harus diselesaikan memiliki waktu cukup sedikit, pada mekanik 3 adalah effort yang artinya lebih mengalami beban usaha yang dikeluarkan. Pada servis berat tahapan dalam penggunaan SWAT sama seperti servis bereat dengan hasil yang diperoleh sebesar $11.11 \%$ yang dikategorikan 
Ringan, dengan prototype dimensi time, effort, stress menonjol pada mekanik 1, 2, dan 3 adalah time yang artinya keseluruhan mekanik lebih mengalami beban usaha waktu dimana mekanik merasa pekerjaan yang harus diselesaikan memiliki waktu cukup sedikit.

\section{Quistionnaire Nordic Body Map (QNBM)}

Hasil QNBM mengambarkan perasaan terhadap keluhan sakit untuk mekanik, dengan persentase $67 \%$ merasakan sakit pada punggung dan pinggang, Serta merasakan agak sakit pada leher atas, bahu kiri dan kanan, lengan atas kiri dan kanan, pinggul, paha kiri dan kanan, lutut kiri dan kanan, dan betis kiri dan kanan sebesar $67 \%$. Pada bagian tubuh lainnya mekanik tidak merasakan sakit.

\section{Pembahasan}

Hasil Penelitian pada PT. XYZ dengan menggunakan metode Quitionaire Nordic Body Map yaitu mekanik merasakan sakit pada bagian tubuh punggung dan pinggang dengan persentasi $67 \%$, artinya dari hasil QNBM menjelaskan untuk seluruh mekanik rentan sakitnya terdapat pada bagian tubuh punggung dan pinggang. Berdasarkan penelitian (Ramdhani dan Zalynda, 2014) pada pengrajin handcraft merasakan keluhan dalam kategori sangat sakit pada punggung dan pinggang yang disebabkan oleh posisi kerja yang tidak baik. Adanya kemiripan dari posisi kerja dan keluhan sakit yang dirasakan, dapat dinyatakan bahwa penerapan postur kerja pada PT. XYZ tidak alamiah. Postur kerja yang tidak baik berakibat terjadinya kelelahan atau berkurangnya kemampuan fisik (Lahay, dkk, 2018), beban kerja mental seseorang dalam suatu pekerjaan dipengaruhi salah satunya adalah faktor individu seperti kelelahan (Hutabarat, 2018). Hal ini juga dapat dilihat dari hasil SWAT dimana beban kerja mental yang dirasakan oleh mekanik pada aktivitas servis berat merasa terbebani, dengan persentasi sebesar $56.6 \%$ pada mekanik 1 dan 3 dimensi effort load. Hal ini berdasarkan observasi awal bahwa Kedua mekanik ini merasa mengeluarkan usaha yang lebih agar bisa menyelesaikan segala pekerjaan yang ditargetkan sehingga tak dapat mengatur postur kerja yang baik untuk diterapkan. Postur kerja yang baik sangat ditentukan oleh pergerakan organ tubuh saat bekerja (Lahay, Hasanuddin, dan Uloli, 2017). Mekanik 2 merasakan beban kerja dimensi time load. Selaras dengan apa yang dirasakan mekanik 2, bahwa aktivitas servis berat membutuhkan ketelitian, olehnya dalam menyelesaikan service berat membutuhkan waktu yang lebih. Pada penelitian (Sunarto, 2018) sebelumnya dengan subjek pekerja di PT. LG Electronics bagian produksi merasakan beban pada dimensi timeload dikarenakan pada pekerjaan PCB membutuhkan ketelitian yang cukup. Hal ini berarti, pekerjaan yang membutuhkkan 
ketelitian yang cukup dengan keterbatasan waktu yang kurang menyebabkan beban pada dimensi time load.

\section{Kesimpulan}

Berdasarkan hasil metode SWAT, beban kerja mental untuk service berat pada mekanik 1 dan 3 presentasinya adalah 56.6\% kategori beban sedang, dengan dimensi effort load, dan pada mekanik 2 adalah dimensi time load dan service ringan $11.11 \%$ beban kerja mental rendah. Mekanik lebih merasakan keluhan pada bagian tubuh punggung, pinggang dengan menggunakan metode Quistionnaire Nordic Body Map dengan persentase adalah $67 \%$ termasuk dalam merasakan sakit.

\section{Daftar Pustaka}

Hutabarat, J. (2018). Koginitif ergonomi: Aplikasi pada pencantingan batik tulis dan sopir angkutan kota. Malang: Mitra Gajayana.

Lahay, I.H., Hasanuddin, dan Uloli, H. (2017). Penilaian postur kerja pada pekerja pembuat batako di Gorontalo. Seminar Nasional Teknologi dan Rekayasa (SENTRA) 2017, pp. 1-6. DOI: https://doi.org/10.22219/sentra.v0i3.1468.

Lahay, I.H., Wolok, E., Hasanuddin, dan Uloli, H. (2018). Pengaruh usia dan lama kerja terhadap kelelahan kerja pada pekerja pembuat batako di Gorontalo. Seminar Nasional Teknologi dan Rekayasa (SENTRA) 2018, pp. 64-67. DOI: https://doi.org/10.22219/sentra.v0i4.2322.

Rahansyah, V.Z. (2019). Kelelahan dan beban kerja mental karyawan di Werehouse PT. Aglity Internasional. Skripsi, Universitas Negeri Gorontalo.

Rahayuningsih, S. (2014). Analisis perbaikan kondisi lingkungan kerja terhadap beban kerja mental. Jurnal Teknik Industri, 15(1), 80-87.

Ramdhani, D. dan Zalynda, P.M. (2014). Analisis postur kerja pengrajin handycraft menggunakan Nordic Body Map dan metode Rapid Upper Limb Assesment (RULA). Scientific Journals, 1-13.

Saputra, A.D, Priyanto, S., Muthohar, I., dan Bhinnety, M. (2019). Analisis beban kerja mental pilot dalam pelaksanaan operasional penerbangan dengan menggunakan metode Subjective Workload Assessment Technique (SWAT). Warta Penelitian Perhubungan, 27(3), 181-194.

Sunarto, N.N. (2018). Analisis beban kerja karyawan dengan menggunakan metode SWAT dan metode NASA TLX (studi kasus di PT. LG Electronics Indonesia). Skripsi, Universitas Islam Indonesia. 